\title{
Redefining Myeloid Cell Subsets in Murine Spleen
}

\author{
Ying-Ying Hey ${ }^{1}$, Jonathan K. H. Tan ${ }^{2}$ and Helen C. O'Neill ${ }^{2 *}$ \\ ${ }^{1}$ Research School of Biology, Australian National University, Canberra, ACT, Australia, ${ }^{2}$ Faculty of Health Sciences and \\ Medicine, Bond University, Robina, QLD, Australia
}

Spleen is known to contain multiple dendritic and myeloid cell subsets, distinguishable on the basis of phenotype, function and anatomical location. As a result of recent intensive flow cytometric analyses, splenic dendritic cell (DC) subsets are now better characterized than other myeloid subsets. In order to identify and fully characterize a novel splenic subset termed "L-DC" in relation to other myeloid cells, it was necessary to investigate myeloid subsets in more detail. In terms of cell surface phenotype, L-DC were

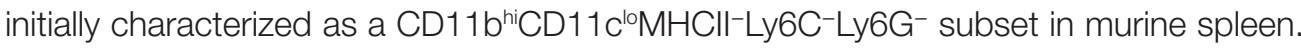
Their expression of CD43, lack of MHCll, and a low level of CD11c was shown to best differentiate L-DC by phenotype from conventional DC subsets. A complete analysis

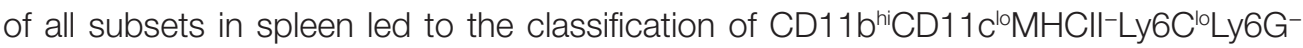
cells as monocytes expressing $\mathrm{CX}_{3} \mathrm{CR} 1, \mathrm{CD} 43$ and CD115. Siglec-F expression was used to identify a specific eosinophil population, distinguishable from both Ly6C ${ }^{10}$ and Ly6C $^{\text {hi }}$ monocytes, and other DC subsets. L-DC were characterized as a clear subset

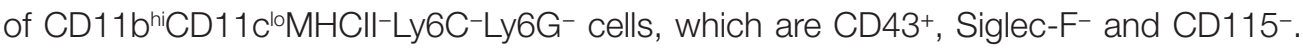
Changes in the prevalence of L-DC compared to other subsets in spleens of mutant mice confirmed the phenotypic distinction between L-DC, CDC and monocyte subsets. L-DC development in vivo was shown to occur independently of the BATF3 transcription factor that regulates $\mathrm{CDC}$ development, and also independently of the FLT3L and GM-CSF growth factors which drive CDC and monocyte development, so distinguishing L-DC from these commonly defined cell types.

Keywords: dendritic cells, monocytes, spleen, myeloid cells

\section{INTRODUCTION}

Characterization of dendritic cell (DC) subsets in spleen has progressed rapidly in terms of phenotype and function; however, other splenic myeloid subsets are less clearly defined. The term "myeloid" has been used as an umbrella term describing DC, granulocytes, and macrophages/monocytes, which descend from a common myeloid progenitor (CMP) in bone marrow (1). Granulocytes comprise neutrophils, eosinophils, basophils, and mast cells (2), while monocytes have been classified into distinct resident and inflammatory populations, in line with monocyte subsets described in peripheral blood (3). Recent definition of a common dendritic progenitor (CDP) now separates the development of conventional (c) and plasmacytoid (p) DC from other myeloid cell types $(4,5)$. The current classification of splenic myeloid subsets is based on cell surface phenotype, although full phenotypic profiles are not yet available. To date, studies focusing on specific subsets do not compare one subset against another to ensure pure populations and do not achieve a comprehensive picture 
of the relationship between subsets. Accurate identification of splenic myeloid cell types is essential for distinguishing specific subsets and their function, and for making studies in the field comparable.

Monocytes develop in bone marrow from CMP and traverse into blood as mature cells (1). Resident monocytes were described as having a longer half-life in blood than inflammatory monocytes (6) and were originally thought to act as precursors of tissue resident macrophages in the steady-state, hence their name "resident" monocytes (7). They were identified further as CC-chemokine receptor 2 (CCR2)- and CX3-chemokine receptor $1\left(\mathrm{CX}_{3} \mathrm{CR} 1\right)^{\mathrm{hi}} \mathrm{Ly} 6 \mathrm{C}^{\mathrm{lo}} \mathrm{Ly} 6 \mathrm{G}^{-}$cells, which play an important role in the detection of vascular integrity $(3,8)$. Inflammatory monocytes were described as distinct as CCR2 ${ }^{+} \mathrm{CX}_{3} \mathrm{CR} 1^{\text {lo }} \mathrm{Ly}_{6 \mathrm{C}}{ }^{\mathrm{hi}} \mathrm{Ly}_{6} \mathrm{G}^{-}$ cells $(3,7,9-11)$. Several studies have now highlighted how tissue-specific macrophages including microglial cells, alveolar macrophages, Langerhans cells and splenic macrophages have a yolk sac-derived origin rather than a bone marrow origin (12-15).

Most studies on monocytes have involved blood as a source of cells, but more recently the relationship between splenic monocytes and their blood counterpart has been considered. The studies of Swirski and colleagues demonstrated that splenic monocytes resemble their blood counterpart on the basis of phenotype, morphology and gene expression (16). Spleen was identified as a reservoir for monocytes, where Ly6 $\mathrm{C}^{\mathrm{hi}}$ inflammatory monocytes were efficiently deployed to sites of inflammation during cardiac arrest. Monocytes in blood and spleen are now identified as cells with a $\mathrm{CD} 11 \mathrm{~b}^{\text {hi }} \mathrm{CD} 11 \mathrm{c}^{-/ \mathrm{lo}}$ phenotype, with further distinction as $\mathrm{Ly} 6 \mathrm{C}^{\text {hi }}$ and Ly6C $\mathrm{C}^{\text {lo }}$ cells resembling inflammatory and residential monocytes, respectively (17). Neutrophils have not been extensively characterized in spleen and were previously delineated on the basis of phenotype as a blood equivalent

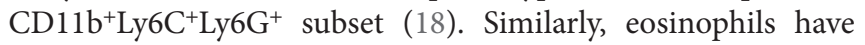
been described in blood as $\mathrm{CD} 11 \mathrm{~b}^{+}$Siglec- $\mathrm{F}^{+} \mathrm{CCR} 3^{+} \mathrm{F} 4 / 80^{+}$cells and in spleen as Ly6C ${ }^{\text {int }} \mathrm{Ly}^{-} \mathrm{G}^{-} \mathrm{SSC}^{\text {hi }}$ Siglec-F+ $\mathrm{F}^{+}$cells $(17,19)$.

The lineage of DC is equally diverse with multiple subsets defined in mice and humans $(20,21)$. All subsets are capable of antigen uptake, processing and presentation for $\mathrm{T}$ cell activation. Conventional $\mathrm{DC}$ are predominant in spleen, comprising $\mathrm{CD}^{-}$and $\mathrm{CD}^{+}$populations, phenotypically distinct as $\mathrm{CD} 11 \mathrm{c}^{\mathrm{hi}} \mathrm{CD} 11 \mathrm{~b}^{+} \mathrm{CD} 8 \alpha^{-} \mathrm{MHCII}^{+}$and $\mathrm{CD} 11 \mathrm{c}^{\text {hi }} \mathrm{CD} 11 \mathrm{~b}^{-} \mathrm{CD} 8 \alpha^{+} \mathrm{MHCII}^{+}$cells, respectively (22). These two dominant DC subsets are distinct in function, cytokine production and ability to cross-present antigen (23). Spleen also contains a smaller population of pDC existing as a plasmacytoid preDC (p-preDC) in the steady-state. These are, however, long-lived, circulating cells, which produce high levels of Type I interferon important in anti-viral immunity (24). Spleen also contains a variable population of poorly defined "myeloid DC." As an example, under inflammatory conditions, circulating CD $115^{+}{\text {Ly } 6 C^{\text {hi }}}$ CCR $2^{+}$monocytes in blood may be recruited into spleen where they differentiate to become "monocyte-derived (mo)-DC” (25-27). Different subsets of mo-DC can subsequently be observed in different disease states.

Novel dendritic-like cells termed L-DC, were recently discovered in murine and human spleen on the basis of their resemblance with dendritic-like cells produced in vitro in splenic long-term cultures (LTC-DC) (28-30), or in co-cultures of bone marrow precursors over selected splenic stroma (31, 32). L-DC have a distinct $\mathrm{CD}_{11} \mathrm{~b}^{\text {hi }} \mathrm{CD} 11 \mathrm{c}^{\mathrm{lo}} \mathrm{MHCII}^{-} \mathrm{CD} 8^{-}$phenotype and dendritic-like appearance (33). Splenic stroma maintains continuous but restricted in vitro development of only this cell type, without addition of cytokines like GM-CSF, M-CSF, or Flt3L used by others to induce DC development in vitro from bone marrow precursors (34). An in vivo equivalent L-DC subset has been partially characterized in spleens of mice and human (35, 36). While L-DC resemble myeloid DC on the basis of CD11c and $\mathrm{CD} 11 \mathrm{~b}$ expression, lack of MHCII expression has raised criticism that L-DC may more resemble splenic monocytes/ macrophages than DC. Low expression of CD11c on L-DC is, however, consistent with some myeloid DC and pDC described as CD11clo cells (37-39).

Analysis of cell surface phenotype using specific antibodies and flow cytometry is widely accepted as a means to identify and distinguish ex vivo cell subsets. A staining protocol and gating strategy were therefore developed here to more accurately delineate and identify DC, monocytes, and other myeloid subsets in spleen. This study now identifies the L-DC subset in vivo as distinct from monocytes, granulocytes and $\mathrm{cDC}$. The development of L-DC has also been investigated in relation to $\mathrm{CDC}$

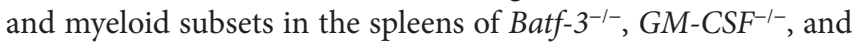
Flt3 $\mathrm{L}^{-1-}$ mutant mice. The GM-CSF and FLT3 ligand (FLT3L) growth factors are known to be important in the differentiation of dendritic and other myeloid cells (34), and the BATF3 transcription factor was recently described as essential for $\mathrm{CD}^{+} \mathrm{cDC}$ development $(40,41)$.

\section{MATERIALS AND METHODS}

\section{Animals}

C57BL/6J mice were bred at the John Curtin School of Medical Research (JCSMR: Canberra, ACT, Australia) under specific pathogen-free conditions. B6.129P(Cg)Ptprc $^{a} C \times 3 C r 1^{\text {tm ILitt }} \operatorname{Litt}$ (Cx3Cr1-GFP) mice were purchased from the Walter and Eliza Hall Institute (Parkville, VIC, Australia). C57BL/6-Flt3L $L^{\text {tmllmx }}\left(\right.$ Flt $\left.3 L^{-/}\right)$mice (Taconic Farms Inc., NY, USA) were purchased from the Biomedical Research Facility, University of Western Australia (Perth, WA, Australia). C57BL/6$C s f 2^{\text {tmlArd }}\left(G M-\mathrm{CSF}^{-/}\right)$mice were obtained from the Ludwig Institute for Cancer Research (Melbourne, VIC, Australia). C57BL/6-129S-Batf ${ }^{m 1.1 K m m} \quad\left(B a t f-3^{-/}\right)$mice were provided through the courtesy of Ian Cockburn (JCSMR). Mice were housed and handled according to the guidelines of the Animal Experimentation Ethics Committee at the Australian National University (Canberra, ACT, Australia).

\section{Cell Fractionation}

Dendritic and myeloid cells were enriched from dissociated whole spleen via negative depletion of $\mathrm{T}, \mathrm{B}$, and red blood cells using magnetic bead separation and MACS $^{\circledR}$ technology (Miltenyi Biotec: Auburn, CA, USA). Depletion was performed by exposing cells to specific antibody, i.e., $0.2 \mu \mathrm{g}$ biotinylated antiThy1.2, anti-CD19, and anti-Ter 119 antibody $/ 10^{8}$ cells in $1 \mathrm{~mL}$ of 
MACS-labeling buffer (2 mM EDTA/0.5\% BSA in PBS) on ice for $25 \mathrm{~min}$. Cells were then washed twice with MACS-labeling buffer, resuspended in buffer $\left(10^{8}\right.$ cells $\left./ \mathrm{mL}\right)$ followed by the addition of $20 \mu \mathrm{L}$ of anti-biotin microbeads $/ 10^{8}$ cells (Miltenyi), with incubation for 25 min on ice. The washing step was repeated, and cells resuspended in MACS-labeling buffer. T, B, and red blood cells were depleted by running cells through LS columns (Miltenyi) in a SuperMACS II Separation Unit (Miltenyi), washing thrice with $3 \mathrm{~mL}$ of buffer and collection of unbound cells as flow-through.

\section{Antibody Staining}

Antibody staining followed by flow cytometry was performed to analyze cell surface marker expression as described previously (32). Non-specific antibody binding via Fc receptors was blocked by incubating cells $\left(\leq 10^{6}\right)$ with anti-CD16/32 (FcBlock) (Biolegend: San Diego, CA, USA) at $5 \mu \mathrm{g} / \mathrm{mL}$. Biotin- or fluorochrome-conjugated antibodies specific for CD11c (N418), CD11b (M1/70), CD8 (53-6.7), CD19 (1D3), CD43 (IBII), Thy1.2 (30H12), Ter119 (Ter-119), F4/80 (CI:A3-1), IA ${ }^{\text {b }(25-9-17), ~ S i g l e c-F ~}$ (E50-2440), Ly6C (HK1.4), and Ly6G (1A8) were purchased from Biolegend. Antibody specific for CD115 (AFS98) was purchased from eBioscience (Parkville, VIC, Australia). Propidium iodide (PI, $1 \mu \mathrm{g} / \mathrm{mL}$ ) was added prior to flow cytometry for discrimination of live and dead cells. Flow cytometry was performed immediately on a BD LSRII flow cytometer (Becton Dickinson: Franklin Lakes, NJ, USA). Data collected included forward scatter (FSC), side scatter (SSC), and multiple fluorescence channels detecting fluorescein isothiocyanate (FITC), phycoerythrin (PE), PI, pacific blue (PB), Alexa Fluor-700, PE-indocyanine-7 (Cy7), allo-phycocyanin (APC), and APC-Cy7. BD FACSDiva Software (Becton Dickinson) was used to acquire data. Analysis of data involved post-acquisition gating using FlowJo software (Tree Star: Ashland, OR, USA). Analyses shown in Figures 1-4 were repeated at least thrice, but only representative data are shown. Replicates are shown for all other experiments.

\section{Cell Sorting}

Cell populations were isolated by sorting following flow cytometry with fluorochrome-conjugated antibodies. Cells were prepared as described above and all incubation and washing steps performed in 1\% fetal calf serum in Dulbecco's Modified Eagle Medium (DMEM). After a final wash prior to sorting, cells were filtered through a $70-\mu \mathrm{m}$ nylon cell strainer (Becton Dickinson) for removal of cell clumps. Cell sorting was performed using a FACSAria cell sorter (Becton Dickinson). Sorted populations were collected in complete medium $(10 \%$ fetal calf serum in DMEM) as described previously (32).

\section{May-Grünwald-Giemsa Staining}

Cell staining with Giemsa was employed to morphologically differentiate cells within sorted populations. Sorted cells $\left(10^{3}-10^{6}\right)$ were pelleted on to a glass slide using a cytospin centrifuge. Cells were fixed in methanol, then stained in a two-step procedure with CliniPure staining solution 1 (0.25\% Eosin YO/Soresen buffer, $\mathrm{pH}$ 6.8) followed by staining solution 2 ( $0.25 \%$ methylene blue polychrone/Soresen buffer, pH 6.8) (HD Scientific: Sydney, NSW, Australia) for $5 \mathrm{~s}$ at each step. Excess solution was rinsed off and slides dried before mounting. Non-aqueous Depex mounting agent (Fluka Analytical: Buchs, Switzerland) was used to prevent leaching of dye from stained cells. Photographs were taken with a LEICA DFC digital camera connected to a LEICA brightfield inverted microscope (LEICA Microsystems: Wetzlar, Germany).

\section{Statistical Analysis}

Data have been presented as mean \pm SE for sample size $n$. For sample size $n \leq 5$, the Wilcoxon Rank-Sum test was used to test significance $(p \leq 0.05)$. Where a normal distribution could be assumed $(n>5)$, Students' $t$-test was used to determine significance $(p \leq 0.05)$.

\section{RESULTS}

\section{Identification of Myeloid Subsets in Spleen}

In blood, both the described populations of Ly6 $\mathrm{C}^{\text {hi }}$ inflammatory and Ly $6 C^{\text {lo }}$-resident monocytes do not express Ly6G (3). Ly6C ${ }^{\text {hi }}$ monocytes are distinct from neutrophils which express Ly6G as well as Ly6C. In order to identify myeloid cells in spleen, $\mathrm{CD}_{11} \mathrm{~b}^{\text {hi }} \mathrm{CD} 11 \mathrm{c}^{-} \mathrm{MHCII}^{-}$cells were initially gated, then further delineated by Ly6C and Ly6G expression to yield subsets with a

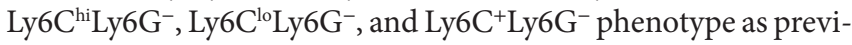
ously described in blood (Figure 1A). These myeloid subsets were then distinguishable on the basis of SSC, with the Ly6C $\mathrm{C}^{\text {hi }}$ subset as SSC $^{\text {lo }}$ cells, Ly6C cells as SSC $^{\text {hi }}$ and neutrophils as SSC $^{\text {mid }}$ (Figure 1A). Staining with antibodies specific for CD11b, CD11c, MHCII, Ly6C and Ly6G, and analysis of SSC can therefore be used to distinguish three main myeloid subsets in spleen, equivalent to those described previously in blood $(7,25)$.

The novel L-DC subset resembles myeloid DC in spleen on the basis of high CD11b expression. In order to further explore the relationship between L-DC and the three major myeloid subsets described above, T, B, and red blood cell-depleted splenocytes were gated as $\mathrm{CD} 11 \mathrm{~b}^{\text {hi }} \mathrm{CD} 11 \mathrm{c}^{\mathrm{lo}} \mathrm{MHCII}^{-}$cells, and further tested for Ly6C and Ly6G expression. Since three distinct populations of cells were observed, Ly6C ${ }^{+} \mathrm{Ly}_{6} \mathrm{G}^{+}(19.9 \%), \mathrm{Ly}^{+} \mathrm{C}^{+} \mathrm{Ly}_{6 \mathrm{G}}{ }^{-}$(27.1\%), and $\mathrm{Ly}^{-} \mathrm{C}^{-} \mathrm{Ly}_{6} \mathrm{G}^{-}(47.1 \%)$ (Figure 1B), these were selected for further study and termed "L-DC candidates." FSC and SSC profiles distinguished $\mathrm{Ly}_{6} \mathrm{C}^{+} \mathrm{Ly} 6 \mathrm{G}^{+}$and $\mathrm{Ly} 6 \mathrm{C}^{+} \mathrm{Ly} 6 \mathrm{G}^{-}$candidates as $\mathrm{FSC}^{\text {hi }} \mathrm{SSC}^{\mathrm{mid}}$, while the $\mathrm{Ly} 6 \mathrm{C}^{-} \mathrm{Ly}^{-} \mathrm{G}^{-}$subset was predominantly FSC $^{\text {lo }} S C^{\text {lo }}$ (Figure 1B). To fully delineate the L-DC subset and to distinguish it from myeloid cells, it was necessary to identify further markers and to characterize all myeloid subsets concurrently.

Ly6 $\mathrm{C}^{\text {lo }}$-resident monocytes in blood were previously distinguished from Ly6 $\mathrm{C}^{\text {hi }}$-inflammatory monocytes on the basis of higher CD43 expression (10). In addition, eosinophils present in steady-state spleen were distinguishable from other myeloid cells through expression of Siglec-F $(17,19)$. Myeloid cells identified in Figure 1 were therefore stained for these markers. All CD $11 b^{\text {hi }} \mathrm{CD} 11 c^{-}$cells delineated by Ly6C and Ly6G expression expressed CD43 (Figure 2A). The majority of Ly6 $\mathrm{C}^{\text {hi }} \mathrm{Ly} 6 \mathrm{G}^{-}$monocytes $(\sim 99 \%)$ and $\mathrm{Ly}^{+} \mathrm{C}^{+} \mathrm{Ly} 6 \mathrm{G}^{+}$neutrophils $(\sim 97 \%)$ did not express Siglec-F (Figure 2B). The Ly6C ${ }^{\mathrm{lo}} \mathrm{Ly}_{6 \mathrm{G}}{ }^{-}$ population contained a distinct $\mathrm{CD} 43^{\text {hi }}$ subset $(83.7 \%)$, which corresponded to $\mathrm{SSC}^{\text {hisiglec }}-\mathrm{F}^{+}$cells and therefore resembled 


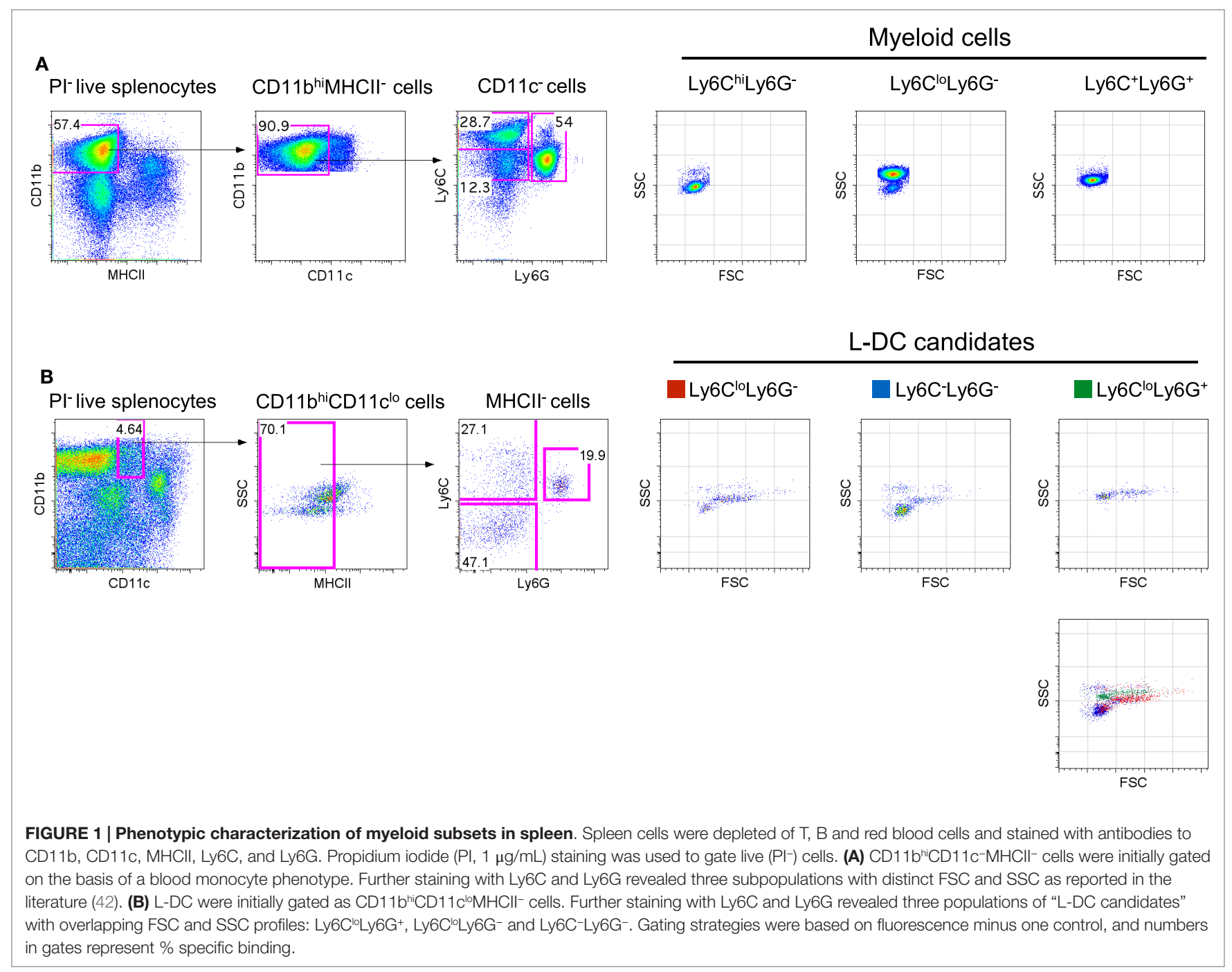

eosinophils (Figures 2A,B). All L-DC candidates, irrespective of Ly6C/Ly6G delineation, expressed CD43 (Figure 2A). The $\mathrm{Ly} 6 \mathrm{C}^{\mathrm{lo}} \mathrm{Ly} 6 \mathrm{G}^{-}$candidates displayed the largest $\mathrm{CD} 43^{\mathrm{hi}}$ population $(40.6 \%)$, also a reflection of resident monocytes. While the majority of cells in all subsets were Siglec- $\mathrm{F}^{-}$, each Ly6C ${ }^{-} \mathrm{Ly}_{6 \mathrm{G}^{-}}$, Ly6C ${ }^{+} \mathrm{Ly}_{6 \mathrm{G}^{-}}$, and $\mathrm{Ly}_{6 \mathrm{C}}{ }^{+} \mathrm{Ly}_{6 \mathrm{G}}{ }^{+}$subset showed some low level contamination with Siglec $-\mathrm{F}^{+}$eosinophils (Figure 2B).

The presence of Siglec- $\mathrm{F}^{+}$cells among splenic myeloid cells therefore necessitated mapping out the eosinophil phenotype in relation to myeloid cells. As shown in Figure 2B, Ly6C ${ }^{\mathrm{lo}} \mathrm{Ly}_{6 \mathrm{G}}{ }^{-}$ myeloid cells contained a large subset of Siglec- $\mathrm{F}^{+}$cells $(79.3 \%)$, indicating a majority of eosinophils. The presence of eosinophils was also confirmed by transcriptome analysis, which revealed specific expression of CCR3 by this subset (unpublished data). In order to confirm the specificity of Siglec-F staining, a backgating strategy was applied to Siglec- $\mathrm{F}^{+}$cells (Figure $\mathrm{S} 1$ in Supplementary Material). Siglec- $\mathrm{F}^{+}$eosinophils were found to be mainly $\mathrm{CD} 11 \mathrm{~b}^{\text {hi }} \mathrm{CD} 11 \mathrm{c}^{-} \mathrm{Ly} 6 \mathrm{C}^{\mathrm{lo}} \mathrm{Ly} 6 \mathrm{G}^{-} \mathrm{CD} 43^{+}$cells. Since this phenotype also reflects $\mathrm{Ly} 6 \mathrm{C}^{\text {lo }}$ monocytes in blood, future stainings therefore involved Siglec-F gating to distinguish or exclude eosinophils from splenic subsets of interest.

The expression of macrophage-colony stimulating factor receptor (M-CSFR/CD115) has also proven useful to delineate monocytes/macrophages and other myeloid subsets (43, 44). Here, it was found that Ly $6 \mathrm{C}^{\mathrm{lo}} \mathrm{Ly} 6 \mathrm{G}^{-}$Siglec- $-\mathrm{F}^{+}$eosinophils were $\mathrm{CD} 115^{-}$, while $\mathrm{Ly} 6 \mathrm{C}^{\mathrm{hi}} \mathrm{Ly}_{6 \mathrm{G}}{ }^{-}$monocytes were $\mathrm{CD} 115^{+}$ (Figure 2C). $\mathrm{Ly} 6 \mathrm{C}^{+} \mathrm{Ly}_{6 \mathrm{G}}{ }^{+}$neutrophils were also CD115-, consistent with reports in the literature (45). Among L-DC candidates, $65 \%$ of the $\mathrm{Ly} 6 \mathrm{C}^{\mathrm{lo}} \mathrm{Ly} 6 \mathrm{G}^{-}$subset, now thought to contain monocytes, expressed CD115. The Ly6C ${ }^{+} \mathrm{Ly}_{6 \mathrm{G}}{ }^{+}$subset of L-DC candidates, thought to be contaminated with neutrophils and other undefined cells, showed $47 \%$ of cells as CD $115^{+}$. However, the Ly6C ${ }^{-} \mathrm{Ly}_{6 \mathrm{G}}{ }^{-}$subset of L-DC candidates was clearly negative for CD115, distinguishing it from other CD $11 b^{\text {hi }} C D 11 c^{\text {lo }} \mathrm{L}-\mathrm{DC}$ candidates (Figure 2C).

\section{Redefining Splenic Myeloid Subsets}

Myeloid subsets in spleen were investigated further in terms of the expression of specific markers which are known to 


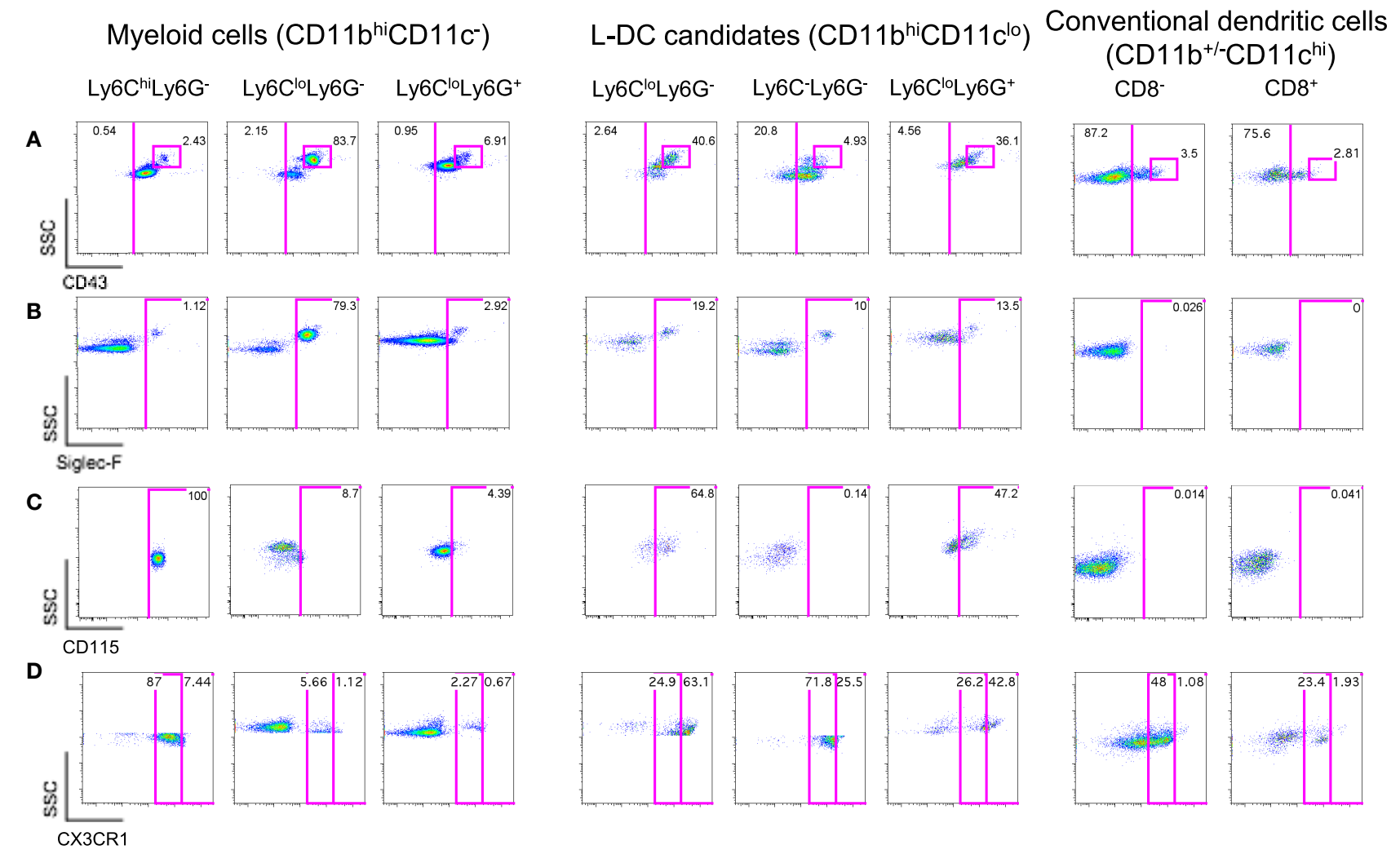

FIGURE 2 | Further delineation of myeloid cells on the basis of CD43, Siglec-F, and CD115 expression. Spleen cells were prepared and stained as described in Figure 1 with the addition of antibodies specific for CD43, CD115, Siglec-F, and CX3CR1. Live (PI-) cells were gated as myeloid cells (CD11 bi CD11 $\left.\mathrm{C}^{-}\right)$

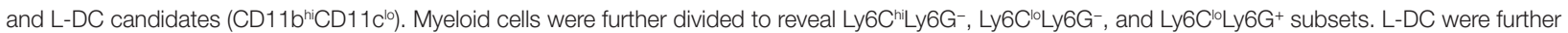
delineated as three candidate subsets differing in Ly6C and Ly6G expression. Expression of (A) CD43, (B) Siglec-F, (C) CD115, and (D) CX3CR1 was determined on all subsets. Gates were set based on fluorescence minus one control, and numbers in gates represent \% specific binding.

distinguish myeloid cells. $\mathrm{CX}_{3} \mathrm{CR} 1$ expression has been associated with the differentiation of macrophages and DC from a macrophage/dendritic progenitor (MDP) (46-48), and Ly6C ${ }^{\text {lo }}$ resident monocytes and $\mathrm{Ly} 6 \mathrm{C}^{\mathrm{hi}}$-inflammatory monocytes in blood have been described as $\mathrm{CX}_{3} \mathrm{CR} 1^{\text {hi }}$ and $\mathrm{CX}_{3} \mathrm{CR} 1^{\text {lo }}$ cells, respectively $(3,7) . \mathrm{CX}_{3} \mathrm{CR} 1$ transgenic mice tagged with green fluorescence protein (GFP) were therefore used to confirm that the subset of $\mathrm{CD} 11 \mathrm{~b}^{\text {hi }} \mathrm{CD} 11 \mathrm{c}^{-} \mathrm{Ly} 6 \mathrm{C}^{\mathrm{lo}} \mathrm{Ly} 6 \mathrm{G}^{-}$Siglec- $\mathrm{F}^{+}$cells did not express $\mathrm{CX}_{3} \mathrm{CR} 1$ in line with the designation of eosinophils. When splenic SSChi $\mathrm{Ly}^{-} \mathrm{G}^{-}$cells corresponding to CD11 ${ }^{\text {hi }} \mathrm{CD} 1$ $1 c^{-}$Ly6 $\mathrm{C}^{\text {lo }}$ Ly6G ${ }^{-}$Siglec- $\mathrm{F}^{+}$cells were gated, very few cells were found to express $\mathrm{CX}_{3} \mathrm{CR} 1$ (6.78\%; Figure 2D), consistent with their classification as eosinophils rather than monocytes. The gated $\mathrm{CD} 11 \mathrm{~b}^{\text {hi }} \mathrm{CD} 11 \mathrm{c}^{-} \mathrm{Ly} 6 \mathrm{C}^{\text {hi }} \mathrm{Ly} 6 \mathrm{G}^{-}$cells were found to be $\mathrm{CX}_{3} \mathrm{CR} 1^{\text {lo }}$, so confirming their identity as Ly $6 \mathrm{C}^{\text {hi }}$-inflammatory monocytes described by Geissmann et al. (7) (Figure 2D). Finally, Ly $6 \mathrm{G}^{+} \mathrm{Ly} 6 \mathrm{C}^{+}$cells were found to be $\mathrm{CX}_{3} \mathrm{CR}^{-}$and so were likely to be neutrophils.

L-DC candidates were then analyzed for $\mathrm{CX}_{3} \mathrm{CR} 1$ expression. For this experiment, they were divided into three populations based on SSC and Ly6G staining, and Ly6C expression on candidate subsets gated on the basis of SSC and Ly6G was also verified by independent staining (data not shown). Of the three L-DC candidate subsets, $\mathrm{SSC}^{\text {hi }} \mathrm{Ly} 6 \mathrm{C}^{\mathrm{lo}} \mathrm{Ly} 6 \mathrm{G}^{-}$cells were largely $\mathrm{CX}_{3} \mathrm{CR} 1^{\text {hi }}$ (63\%), and along with their CD115 expression, reflected a phenotype consistent with Ly6 $\mathrm{C}^{\mathrm{lo}}$ monocytes (Figure 2D). The Ly $6 \mathrm{C}^{+} \mathrm{Ly}_{6 \mathrm{G}}{ }^{+}$subset classified as neutrophils appeared heterogeneous with $43 \% \mathrm{CX}_{3} \mathrm{CR} 1^{\text {hi }}$ cells. The SSClo Ly6C ${ }^{-} \mathrm{Ly}_{6} 6 \mathrm{G}^{-} \mathrm{L}-\mathrm{DC}$ candidate, negative for CD115 expression, was also $\mathrm{CX}_{3} \mathrm{CR} 1^{+}$. Low $\mathrm{CX}_{3} \mathrm{CR} 1$ expression was also observed on $48 \%$ of gated CD8 ${ }^{-}$ $\mathrm{cDC}$ and $23 \%$ of gated $\mathrm{CD} 8^{+} \mathrm{cDC}$ (Figure 2D), consistent with previous reports $(49,50)$. In terms of L-DC, the expression of $\mathrm{CX}_{3} \mathrm{CR} 1$ on $\mathrm{SSC}^{\mathrm{l}} \mathrm{Ly} 6 \mathrm{C}^{-} \mathrm{Ly}_{6 \mathrm{G}}^{-}$cells is consistent with a dendritic/ monocyte cell type.

\section{L-DC Are Morphologically Distinct from Monocytes}

In order to classify subsets further, myeloid and DC subsets were sorted to purity, prepared as cytospins, and visualized by Giemsa staining. Light microscopy was used to identify and quantitate cells based on morphology. Among $\mathrm{CD} 11 \mathrm{~b}^{\text {hi }} \mathrm{CD} 11 \mathrm{c}^{-}$myeloid cells, the Ly6C $\mathrm{C}^{+} \mathrm{Ly} 6 \mathrm{G}^{+}$subset (also $7 / 4^{+}$Siglec-F ${ }^{-}$) demonstrated characteristic neutrophil morphology, with a multi-lobate 


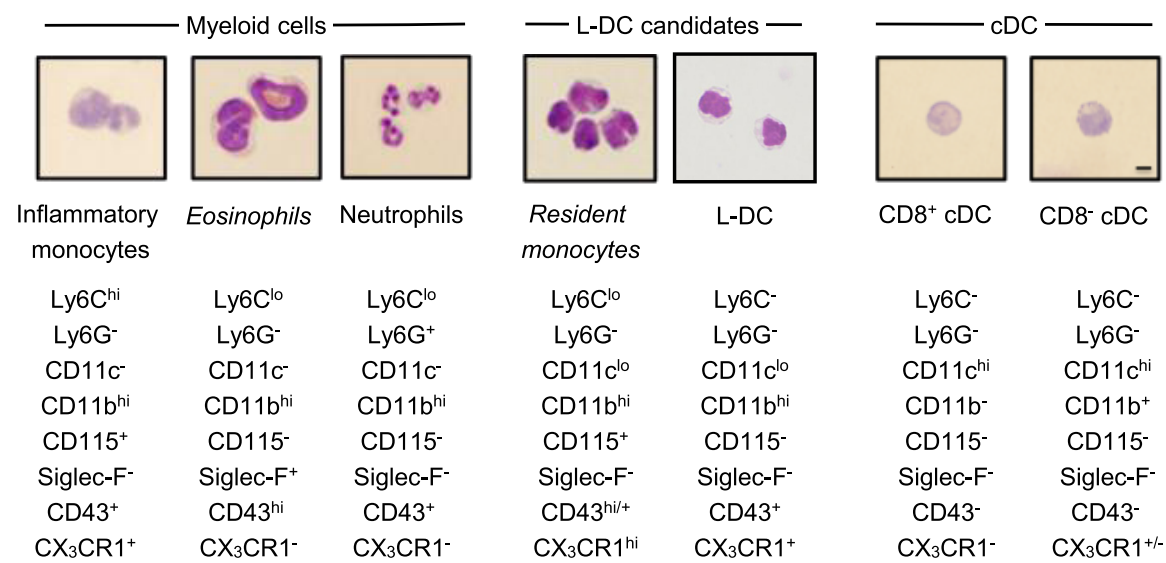

FIGURE 3 | Morphology of spleen dendritic and myeloid subsets. Splenocytes were sorted into myeloid subsets, L-DC candidates and cDC as described in Figure 2. Sorted subsets were cytospun on to slides and fixed prior to Giemsa staining. Photomicroscopy of subsets was performed at $600 \times$ magnification, bar $10 \mu \mathrm{m}$. Italicized labels indicate revised subset classification based on identified morphology and cell surface phenotype. Ly6C $\mathrm{C}^{\text {hi }}$ and $L y 6 C^{l o}$ monocytes are labeled as inflammatory and resident monocytes, respectively.

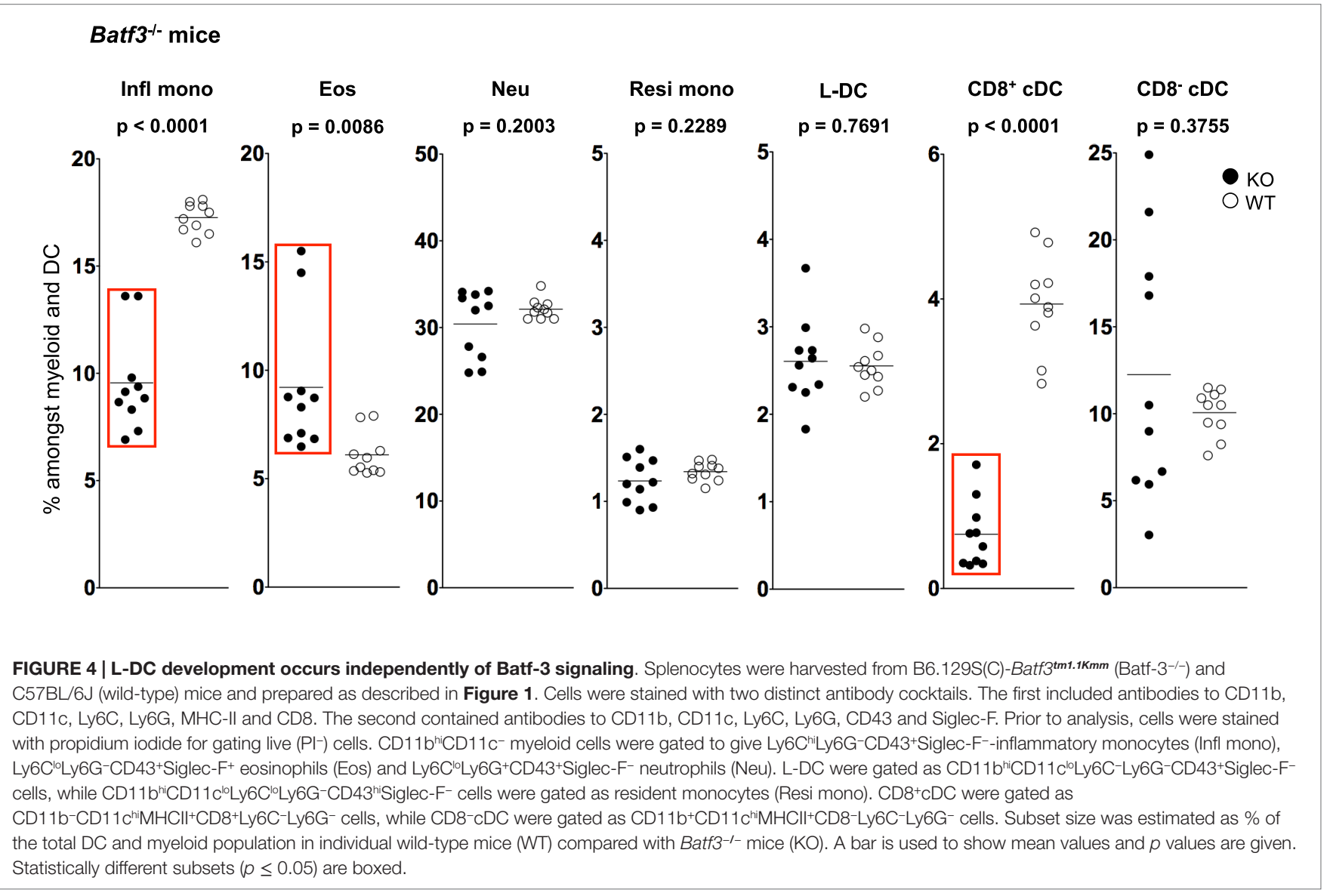

nucleus and cytoplasm devoid of granules (Figure 3). Over two independent experiments, all cells counted from this subset showed similar neutrophil morphology (Table 1). Giemsa stain-

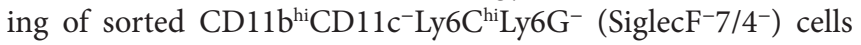

revealed a bi-lobate nucleus and a cytoplasm devoid of granules (Figure 3). The majority of cells (>90\%) displayed this morphology (Table 1), confirming the phenotype of Ly6 $\mathrm{C}^{\mathrm{hi}}$-inflammatory monocytes. Gated $\mathrm{CD}_{11} \mathrm{~b}^{\text {hi }} \mathrm{CD} 11 \mathrm{c}^{-} \mathrm{Ly}_{6 \mathrm{C}}{ }^{\mathrm{lo}} \mathrm{Ly}_{6 \mathrm{G}}{ }^{-}\left(\right.$SiglecF $\left.^{+} 7 / 4^{-}\right)$ 
TABLE 1 | Morphological characterization of spleen dendritic and myeloid subsets.

\begin{tabular}{|c|c|c|c|c|c|c|c|}
\hline \multirow[t]{2}{*}{ Sorted subset } & \multirow{2}{*}{$\begin{array}{l}\text { Subset } \\
\text { classification }\end{array}$} & \multirow[t]{2}{*}{ Expt ${ }^{a}$} & \multirow{2}{*}{$\begin{array}{l}\text { No. of } \\
\text { cells }\end{array}$} & \multicolumn{4}{|c|}{$\%$ cells with known morphologyb } \\
\hline & & & & Eosinophil & Neutrophil & Monocyte-like & Dendritic-like \\
\hline \multirow[t]{2}{*}{ CD11b $^{\text {hi } C D 11 c^{-} \text {Ly6C }^{\text {hilLy6G }}{ }^{-} \text {CD43+Siglec-F- }}$} & Inflammatory & 1 & 72 & 1.4 & - & $97.2^{c}$ & 1.4 \\
\hline & monocytes & $\|$ & 68 & 1.5 & - & 86.8 & 11.8 \\
\hline \multirow[t]{2}{*}{ 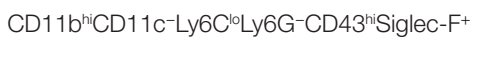 } & Eosinophils & 1 & 72 & 100 & - & - & - \\
\hline & & $\|$ & 72 & 100 & - & - & - \\
\hline \multirow[t]{2}{*}{ CD11b ${ }^{\text {hi CD11c-Ly6C }}{ }^{10}$ Ly6G $^{+}$CD43+Siglec-F- } & Neutrophils & 1 & 26 & - & 100 & - & - \\
\hline & & $\|$ & 18 & - & 100 & - & - \\
\hline \multirow[t]{2}{*}{ 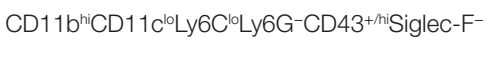 } & Resident monocytes & 1 & 76 & - & - & 68.4 & 31.6 \\
\hline & & $\|$ & 80 & - & - & 62.5 & 37.5 \\
\hline \multirow[t]{2}{*}{ CD11b ${ }^{\text {hi }}$ CD11 $c^{l o}$ Ly6C-Ly6G-CD43+Siglec-F- } & L-DC & 1 & 78 & 10.3 & - & 42.3 & 47.4 \\
\hline & & $\|$ & 84 & 6.0 & - & 32.1 & 62 \\
\hline \multirow[t]{2}{*}{ CD11b-CD11 chil Ly6C-Ly6G-CD43-Siglec-F- } & $\mathrm{CD} 8^{+} \mathrm{cDC}$ & 1 & 41 & - & - & 26.8 & 73.2 \\
\hline & & $\|$ & 34 & - & - & 17.7 & 82.4 \\
\hline \multirow[t]{2}{*}{ CD11b+CD11 chil Ly6C-Ly6G-CD43-Siglec-F- } & CD8- cDC & । & 61 & - & - & 13.1 & 86.9 \\
\hline & & $\|$ & 59 & 1.7 & - & 15.3 & 83.1 \\
\hline
\end{tabular}

aData are shown for two independent sorting experiments.

${ }^{b}$ Cells were cytospun and stained with Giemsa for microscopic classification.

'Dominant subsets are shown in bold.

cells demonstrated multi-lobate nuclei with clear presence of orange granules in the cytoplasm, consistent with eosinophils and confirming a Siglec- $\mathrm{F}^{+}$identity (Figure 2).

Among the $\mathrm{CD}^{+}$and $\mathrm{CD} 8^{-} \mathrm{cDC}$ subsets, a majority (80-90\%) of cells displayed the morphology of mononuclear dendritic-like cells with vacuoles evident in the cytoplasm and nuclei staining blue (Table 1; Figure 3). Among the $\mathrm{CD} 11 \mathrm{~b}^{\mathrm{hi}} \mathrm{CD} 11 \mathrm{c}^{\mathrm{lo}}$ candidates, the $\mathrm{Ly} 6 \mathrm{C}^{+} \mathrm{Ly} 6 \mathrm{G}^{-}$subset revealed morphology resembling monocytes with a bi-lobate nucleus and a cytoplasm devoid of granules (Figure 3). Combined with a SiglecF ${ }^{-} \mathrm{CD} 43^{\text {thi }} \mathrm{CX}_{3} \mathrm{CR} 1{ }^{\text {hi }} \mathrm{CD} 115^{+}$ phenotype, this population is reflective of $\mathrm{Ly}^{6} \mathrm{C}^{\mathrm{lo}}$ monocytes. A subpopulation of $\sim 30 \%$ cells, however, was observed to show morphology more typical of DC (Table 1), and this could indicate an impure population. The $\mathrm{Ly}_{6} \mathrm{C}^{+} \mathrm{Ly}_{6 \mathrm{G}} \mathrm{G}^{+}$subset comprised mainly neutrophils, with $\sim 10 \%$ monocytes (data not shown). Sorted Ly6C- ${ }^{-}$6 $6 G^{-}$L-DC were also heterogeneous, with the presence of both dendritic-like and monocyte-like cells. Across two experiments, 47 and $62 \%$ of cells displayed a mononuclear dendriticlike morphology with veiled membranes, short dendrites, and vacuoles evident in the cytoplasm, with $30-40 \%$ of cells showing more monocyte-like morphology (Table 1; Figure 3). Five to ten percent of cells represented eosinophils as a potential contaminant identified in Figure 2. Overall, Giemsa staining revealed the presence of a majority of dendritic-like cells in the CD11 $\mathrm{b}^{\mathrm{h}}$ ${ }^{\mathrm{i}} \mathrm{CD} 11 \mathrm{c}^{\mathrm{lo}} \mathrm{Ly} 6 \mathrm{C}^{-} \mathrm{Ly} 6 \mathrm{G}^{-}$subset, and based on collective data, this subset most likely represents L-DC, with monocytes representing the major subpopulation of $\mathrm{Ly}_{6} \mathrm{C}^{+} \mathrm{Ly} 6 \mathrm{G}^{-}$cells, and neutrophils comprising most of the $\mathrm{Ly} 6 \mathrm{C}^{+} \mathrm{Ly} 6 \mathrm{G}^{+}$subset.

\section{L-DC Are a Distinct Lineage from cDC}

While L-DC are phenotypically distinct from CDC, they show similarity in their endocytic and cross-presentation ability (36). To determine if L-DC and $\mathrm{CDC}$ derive from a common lineage progenitor, their prevalence was investigated in $\mathrm{Batf}^{-{ }^{--}}$mice. The expression Batf3 has been described for pre-cDC, with peak expression in differentiated $\mathrm{CD} 8^{+}$and $\mathrm{CD} 8^{-} \mathrm{CDC}(51-53)$.
Batf $3^{-/-}$mice contain decreased numbers of $\mathrm{CD}^{+} \mathrm{cDC}$, but not $\mathrm{CD} 8^{-} \mathrm{cDC}$, suggesting that Bat 3 is essential in the development of $\mathrm{CD}^{+}{ }^{+} \mathrm{cDC}$ from pre-cDC (51). Batf3 may co-operate with another factor to induce the final differentiation of $\mathrm{CD}^{+} \mathrm{cDC}$, while $\mathrm{CD}^{-} \mathrm{cDC}$ differentiation may occur independently of Batf3 (52).

The proportional representation of dendritic and other myeloid subsets in spleen relative to total splenic myeloid subsets of $\mathrm{CD} 11 \mathrm{~b}^{+}$and/or CD11 $\mathrm{c}^{+}$cells was compared in mutant and wild-type mice. Subsets were delineated as described in Figure 3 and Table 1. A significant drop in the number of $\mathrm{CD}^{+} \mathrm{CDC}$ was observed in Batf $3^{-/}$mice compared with wild-type mice consistent with previous reports (Figure 5). However, the number of $\mathrm{CD}^{-} \mathrm{cDC}$ in Batf3 $3^{-1-}$ varied with 4 of $10 \mathrm{Batf}^{3^{--}}$mice showing an increase in $\mathrm{CD}^{-} \mathrm{CDC}$, while another four showed lower numbers of $\mathrm{CD}^{-} \mathrm{CDC}$ compared with controls. Variability in $\mathrm{CD}^{-}$cDC numbers could suggest either multiple interactive effects leading to highly variable numbers, or heterogeneity among the $\mathrm{CD}^{-} \mathrm{cDC}$ subset delineated here. The percentage of Ly6C $\mathrm{C}^{\text {hi }}$-inflammatory monocytes also dropped significantly in Batf $3^{-/}$mice (Figure 4). L-DC, Ly6C $\mathrm{C}^{\mathrm{lo}}$-resident monocytes, and neutrophils displayed no change in percentage due to the Batf3 mutation. Eosinophils were the only cells that displayed an increase in percentage in $\mathrm{Batf}^{-/-}$mice, but this could be consistent with increased inflammation in these mice.

\section{L-DC Develop Independently of FLT3L and GM-CSF}

Fms-like tyrosine kinase 3 (FLT3) signaling has been described as essential for $\mathrm{CDC}$ development in steady-state spleen (54). Administration of FLT3L during in vitro and in vivo cell development leads to an increase in the number of splenic cDC and pDC (55-57). Similarly, knockdown of Flt3L leads to a two- to threefold drop in the number of splenic $\mathrm{CDC}$ and $\mathrm{pDC}$ in adult mice (54). In order to investigate whether L-DC development is also dependent on FLT3L, the percentage representation of $\mathrm{CDC}$, 


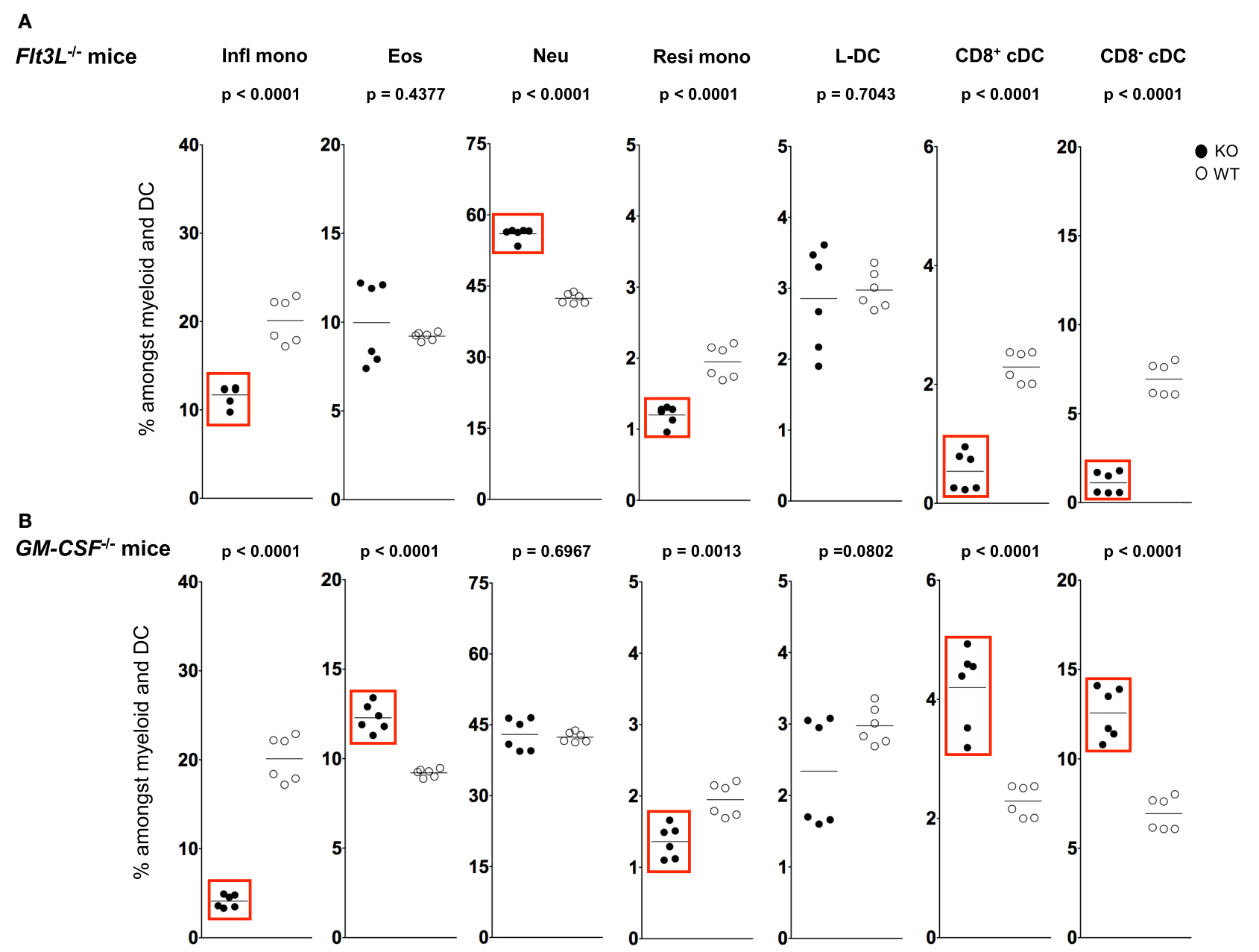

FIGURE 5 | L-DC development occurs independently of Flt3L and GM-CSF. Splenocytes were harvested from C57BL/6J-Flt3L ${ }^{\text {tm1lmx }}$ (Flt3L ${ }^{-/-}$), C57BL/6JCsf2 ${ }^{\text {tm1Ard }}\left(\mathrm{GM}^{\mathrm{CSSF}}{ }^{-/-}\right)$, and C57BL/6J (wild-type) mice, and prepared as described in Figure 1. Cells were stained with two distinct antibody cocktails and propidium iodide $(\mathrm{Pl})$ as described in Figure 4. Subset size was estimated as \% of total DC and myeloid population in individual wild-type mice (WT) compared with (A) Flt3L $L^{-1-}$ and (B) GM-CSF ${ }^{-1-}$ mice (KO). A bar is used to show mean values and $p$ values are given. Statistically different subsets ( $\left.p \leq 0.05\right)$ are boxed.

L-DC and other myeloid subsets was analyzed relative to the total dendritic and myeloid cell population in adult $F l t 3 L^{-/-}$and wild-type mice.

A sixfold reduction in proportion of CD11c hi cells was observed in Flt3L $L^{-1-}$ mice compared with wild-type mice, consistent with the literature $(58,59)$ (data not shown). A significant $\sim 7$-fold drop in percentage $\mathrm{CD}^{-}{ }^{-} \mathrm{cDC}$ among total dendritic and myeloid cells, and a significant drop in percentage of $\mathrm{CD}^{+}$ cDC were observed in Flt $3 \mathrm{~L}^{-/-}$mice compared with wild-type mice (Figure 5A). There was also a significant drop in the percentage of Ly6 $\mathrm{C}^{\text {hi }}$ inflammatory and Ly6 $6 \mathrm{C}^{\mathrm{lo}}$-resident monocytes in Flt3 $L^{-1-}$ mice (Figure 5A). In contrast, neither L-DC nor eosinophils were affected by absence of Flt3L expression during development. Last, the percentage of neutrophils increased in Flt3 $\mathrm{L}^{-1-}$ mice (Figure 5A). These results predict a role for FLT3L in the development of cDC, and all monocytes, but not L-DC and eosinophils. The proportional increase in neutrophils could reflect inflammation in a mouse model which has reduced immune capacity.

During inflammation, Ly6 $\mathrm{C}^{\text {hi }}$ monocytes can give rise to mo-DC that produce TNF- $\alpha$ and inducible NO synthase. These have been called "Tip-DC" $(7,42,60)$. Similarly, granulocytemacrophage colony-stimulating factor (GM-CSF) can induce formation of inflammatory type mo-DC after addition to cultures of bone marrow progenitors $(34,61,62)$. In order to investigate a role for GM-CSF in the development of splenic dendritic and other myeloid subsets, changes in the populational representation of $\mathrm{CDC}, \mathrm{L}-\mathrm{DC}$ and myeloid subsets were investigated in GM-CSF${ }^{-1-}$ mice (Figure 5B). Previous studies have reported no change in the proportion of $\mathrm{pDC}$ and $\mathrm{CDC}$ in $\mathrm{GM}-\mathrm{CSF}^{-1-}$ mice (63, 64). In this study, however, percentages of both $\mathrm{CD}^{+} \mathrm{CDC}$ and $\mathrm{CD}^{-} \mathrm{cDC}$ were higher in $\mathrm{GM}-\mathrm{CSF}^{-/-}$mice (Figure 5B), while percentages of both Ly6 $\mathrm{C}^{\text {hi }}$ and Ly6 $\mathrm{C}^{\text {lo }}$ were significantly lower (Figure 5B). The percentage of eosinophils in $\mathrm{GM}^{-C S F^{-/-}}$mice 
was significantly increased, while the percentage of neutrophils remained unaffected (Figure 5B). Proportional representation of L-DC was not significantly different, although more variable in $G M-C S F^{-/-}$compared with wild type mice.

L-DC development therefore occurs independently of both FLT3L and GM-CSF, while the development of monocyte subsets is clearly dependent on both factors (Figure 5). While cDC subsets are dependent on FLT3L for development, they develop independently of GM-CSF. In fact, in the absence of GM-CSF, there appears to be a compensatory increase in the development of cDC as well as eosinophils (Figure 5). These results distinguish L-DC from both $\mathrm{CDC}$ and other myeloid subsets, since L-DC develop independently of BATF3, FLT3L and GM-CSF.

\section{DISCUSSION}

In addressing the issue of myeloid cell subset classification in spleen, a recent paper suggested a unified nomenclature for DC, monocytes, and macrophages based primarily on ontogeny, and secondly by location, function, and phenotype (65). The delineation of splenic Ly6 $\mathrm{C}^{\text {lo }}$ monocytes was made on the basis of the described phenotype and function of previously described resident monocytes in blood $(7,25)$. Now, it is shown here that the spleen contains distinct populations of $\mathrm{Ly} 6 \mathrm{C}^{\mathrm{hi}} \mathrm{CD} 11 \mathrm{c}^{-}$and Ly6 $\mathrm{C}^{\text {lo }} \mathrm{CD} 11 \mathrm{c}^{\text {lo }}$ monocytes, as well Ly $6 \mathrm{C}^{\mathrm{lo}} \mathrm{CD} 11 \mathrm{c}^{-}$eosinophils. The latter population appears to be present in higher number in spleen and so more likely to obscure the $\mathrm{Ly} 6 \mathrm{C}^{\mathrm{lo}} \mathrm{CD} 11 \mathrm{c}^{\text {lo }}$ monocyte population in the absence of staining for CD11c and the SiglecF marker specific for eosinophils.

In order to better define an in vivo equivalent L-DC population in relation to splenic myeloid subsets, it was necessary to analyze dendritic and other myeloid subsets concurrently. Since blood monocytes are the most widely characterized monocytes, their phenotype was used as the starting point for analysis of splenic monocytes $(19,47)$. Ly6C ${ }^{\text {lo }}$ and Ly6 $\mathrm{C}^{\text {hi }}$ monocytes in blood were previously described as

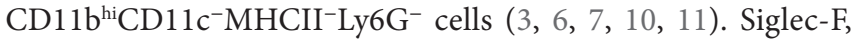
an inhibitory receptor expressed by murine eosinophils (66, 67) proved definitive for analysis of eosinophils in this subset (Figure 2). The $\mathrm{CD}_{11} \mathrm{~b}^{\text {hi }} \mathrm{CD} 11 \mathrm{c}^{-} \mathrm{MHCII}^{-} \mathrm{Ly} 6 \mathrm{C}^{+} \mathrm{Ly}_{6 \mathrm{G}}^{-}$subset of cells in spleen was found to comprise a majority $(87 \%)$ of Siglec- $\mathrm{F}^{+}$eosinophils (Figure 2), with Ly6 $\mathrm{C}^{\text {hi }}$ monocytes clearly Siglec- $\mathrm{F}^{-}$(Figure 2). The results of this study now confirm the definition of splenic Ly6C $\mathrm{C}^{\text {lo }}$ monocytes as CD11 $c^{\text {lo }}$ cells $(9,10$, 68) lying within the $\mathrm{Ly} 6 \mathrm{C}^{+} \mathrm{Ly}_{6 \mathrm{G}} \mathrm{G}^{-}$population.

To further test these initial predictions, the myeloid markers $\mathrm{CX}_{3} \mathrm{CR} 1$ and $\mathrm{CD} 115$ were employed. $\mathrm{CX}_{3} \mathrm{CR} 1$ is a known marker of Ly6C $C^{\text {lo }}$-resident monocytes $(7,25)$, and CD115 is a marker of bone marrow-derived myeloid cells $(43,44)$. High levels of $\mathrm{CX}_{3} \mathrm{CR} 1$ were shown to be expressed by $\mathrm{CD} 11 \mathrm{c}^{\text {lo }}$ cells that were also $\mathrm{Ly} 6 \mathrm{C}^{\mathrm{lo}} \mathrm{Ly} 6 \mathrm{G}^{-}$, so confirming their similarity with resident monocytes (Figure 2D). In addition, these cells also expressed CD115 (Figure 2C). Since CD115 was not expressed by the putative L-DC subset, this suggests different lineage origins for L-DC and Ly6 $\mathrm{C}^{\text {lo }}$ monocytes. In line with the literature, Ly6C $\mathrm{C}^{\text {hi }}$ monocytes are CD115', while both neutrophils and eosinophils lacked CD115 expression (Figure 2C).
Phenotypic studies were informative although not definitive in the identification of L-DC in relation to other myeloid subsets. Morphological characterization by May-Grünwald-Giemsa staining was used to confirm predicted subsets. Blood monocytes have a bi-lobate nucleus and minimal cytoplasm devoid of granules (Figure 4) $(7,10)$. Ly6 $\mathrm{C}^{\text {hi }}$ monocytes in spleen displayed this morphology in line with their blood cell counterparts (Figure 4) $(16,19)$. Giemsa staining also confirmed that the splenic subset defined here as eosinophils had a characteristic multi-lobate nucleus with orange granules in the cytoplasm, consistent with their phenotypic classification as Siglec- $\mathrm{F}^{+}$eosinophils (Figure 4) (69). The identified Ly6 $\mathrm{C}^{\text {lo }}$ monocyte subset identified as CD11 $c^{\text {lo }}$ cells displayed morphology consistent with blood monocytes and not DC. These cells had a bi-lobate nucleus with minimal cytoplasm which lacked granules (Figure 3). Therefore morphological studies supported phenotypic studies, showing that spleen resident Ly6C ${ }^{\text {lo }}$ monocytes lie within the $\mathrm{CD} 11 \mathrm{~b}^{\text {hi }} \mathrm{CD} 11 \mathrm{c}^{\mathrm{lo}} \mathrm{Ly} 6 \mathrm{C}^{+}$ Ly $6 \mathrm{G}^{-}$population. Morphological analysis also showed that all Ly $6 \mathrm{G}^{+}$subsets comprised a majority of neutrophils with characteristic multi-lobate nucleus (Figure 4). This was also confirmed by their $7 / 4$ staining (data not shown).

The morphology of splenic DC is known to be to be quite distinct from the first described DC subset of Langerhans cells, which have long membrane projections $(70,71)$. Here, $\mathrm{CD}^{+}$ cDC were shown to reflect a majority of mononuclear cells with vacuoles evident in the cytoplasm. Similarly, $\mathrm{CD} 8^{-} \mathrm{cDC}$ and up to $60 \%$ of the Ly6 $\mathrm{C}^{-} \mathrm{Ly} 6 \mathrm{G}^{-} \mathrm{L}-\mathrm{DC}$ subset also demonstrated similar cDC morphology with cytoplasmic vacuoles (Figure 3). These cells also showed veiled membranes with a few small dendrities, although this cannot be clearly be distinguished on cytospun cells. Combined phenotypic and morphological studies therefore identify L-DC as a subset of CD $11 b^{\text {hi }} \mathrm{CD} 11 \mathrm{c}^{\text {lo }} \mathrm{Ly} 6 \mathrm{C}^{-} \mathrm{Ly}_{6 \mathrm{G}}{ }^{-}$cells, with the majority demonstrating the morphology of a DC. A combination of studies shown here, therefore identify L-DC as a distinct cell type, reflecting the in vivo equivalent of cells produced in longterm cultures of spleen, LTC-DC. While it has been possible to phenotypically and morphologically identify an in vivo counterpart of the in vitro-produced L-DC, classification of this cell type as dendritic will be dependent on demonstration of their ability to activate naïve T cells and to cross present antigen as shown previously for in vitro produced cells $(31,33)$.

Knockout mice studies have played a definitive role in identifying genes essential for development. Since none of the mutant mice studied here are embryonically lethal, and none of the genes mutated are crucial for survival, it was possible to obtain essential information about the development of L-DC in relation to other splenic myeloid subsets. CD $11 \mathrm{~b}^{\text {hi }} \mathrm{CD} 11 \mathrm{c}^{\mathrm{lo}} \mathrm{Ly} 6 \mathrm{C}^{-}$ Ly $6 \mathrm{G}^{-}$L-DC development occurs independently of factors that regulate $\mathrm{cDC}$ and monocyte development, including BATF3, FLT3L, and GM-CSF. These findings distinguish L-DC from CDC as a separate lineage of cells, and identify them as distinct from splenic monocyte and granulocyte subsets.

Previously, this lab published evidence that L-DC can arise in vitro from self-renewing bone marrow-derived hematopoietic stem cells (HSC) and multipotential progenitors (MPP) following co-culture over splenic stromal lines $(72,73)$. These findings confirm that L-DC arise from a progenitor distinct from the CDP 
also present in bone marrow (74). The production of L-DC was unaffected in Batf- $3^{-/-}$mice, suggesting that L-DC develop as a distinct lineage separated from cDC. In Batf- $3^{-1-}$ mice, a significant drop in the percentage of inflammatory monocytes was also observed. Recent studies in Batf- $3^{-/-}$mice also showed a defect in the differentiation of CD4 T helper cells into T helper 17 (Th17) cells $(75,76)$ essential for supporting inflammatory responses involving pathogens or autoimmunity $(77,78)$. It is interesting to speculate that Ly6C $\mathrm{C}^{\text {hi }}$ monocytes may be important mediators of Th17 cell development from $\mathrm{CD}^{+} \mathrm{T}$ helper cells.

The binding of FLT3L to FLT3 triggers the development of cDC from pre-cDC $(34,63,79)$, and the knockout of either Flt3 or Flt3L adversely affects cDC development $(63,79)$. In this study, a significant drop in the production of splenic $\mathrm{CD}^{+} \mathrm{CDC}$ and CD8 ${ }^{-}$cDC was observed in Flt3 $L^{-/-}$mice $(34,63)$. FLT3 is also a marker of common lymphoid progenitors (CLP) and CMP (59), such that the delivery of additional FLT3L to mice can lead to an expansion of the monocyte pool along with $\operatorname{cDC}(58,59)$. Expression of the FLT3 receptor on myeloid precursors, and the development of monocytes following FLT3L stimulation suggests that FLT3 receptor tyrosine kinase signaling plays a role in monocyte development. In agreement with this, Waskow et al. (79) showed an increase in the numbers of MDP which give rise to CDP and monocytes following FLT3L stimulation in vivo and in vitro. A reduction in the number of Ly $6 \mathrm{C}^{\text {lo }}$ resident and $\mathrm{Ly}_{6 \mathrm{C}} \mathrm{C}_{\text {h }}$ inflammatory monocytes in Flt3 $\mathrm{L}^{-1-}$ mice shown here also supports a role for FLT3 signaling in monocyte development. Since L-DC development is not compromised in Flt $3 \mathrm{~L}^{-/-}$mice, L-DC are distinguishable in terms of development and lineage origin from both $\mathrm{cDC}$ subsets, and from the major monocyte subsets in spleen.

Both FLT3L and GM-CSF have been used for in vitro expansion of DC. Previously, it was shown that the culture of bone marrow precursors with FLT3L-generated $\mathrm{cDC}$ and $\mathrm{pDC}$, while GM-CSF in the same system, generated inflammatory mo-DC $(61,63) . G M-C S F^{-1-}$ mice were employed here to determine any role for GM-CSF in the in vivo development of L-DC. Deficiency in GM-CSF production did not affect the development of L-DC, suggesting that L-DC are not likely to be an inflammatory type cell dependent on GM-CSF signaling for development from myeloid precursors. By comparison, in $G M-C S F^{-1-}$ mice, the percentage of the two main monocyte subsets was reduced, consistent with their development in response to GM-CSF and probably inflammation. The percentage of Ly6 $\mathrm{C}^{\text {hi }}$-inflammatory monocytes was fourfold lower in GM-CSF-/- mice, while Ly6C ${ }^{\text {lo }}$ resident monocytes showed a smaller but significant 1.4 -fold reduction. Previous studies in $G M-C S F^{-1-}$ mice showed no significant change in peripheral blood myeloid subsets, although alveolar macrophages were found to be defective (80). However,

\section{REFERENCES}

1. Akashi K, Traver D, Miyamoto T, Weissman IL. A clonogenic common myeloid progenitor that gives rise to all myeloid lineages. Nature (2000) 404:193-7. doi:10.1038/35004599

2. Hickey MJ, Kubes P. Intravascular immunity: the host-pathogen encounter in blood vessels. Nat Rev Immunol (2009) 9:364-75. doi:10.1038/nri2532 that study did not investigate splenic myeloid subsets to the level of phenotypic detail used here. Under steady-state conditions, the development of cDC occurs independently of GM-CSF (63). In this study, the percentage of $\mathrm{CD}^{+} \mathrm{CDC}$ and $\mathrm{CD} 8^{-} \mathrm{CDC}$ was found to be significantly increased in $G M-C S F^{-1-}$ mice, although an increase in $\mathrm{CDC}$ numbers could occur as a compensatory change in spleen due to reduction in the number of monocytes. This study also showed that eosinophils increased in number in spleens of $G M-C S F^{--}$mice, suggesting that the development of eosinophils occurs independently of GM-CSF. An increase in eosinophil number could also reflect an inflammatory or allergic state in $G M-C S F^{-1-}$ mice.

In conclusion, a novel dendritic-like cell type termed L-DC has been defined among multiple spleen myeloid subsets as $\mathrm{CD}_{11 b^{\text {hi }}} \mathrm{CD} 11 \mathrm{c}^{\text {lo }} \mathrm{MHCII}{ }^{-} \mathrm{CD} 43^{\text {lo }} \mathrm{CD} 115^{-}$Siglec-F ${ }^{-} \mathrm{CX}_{3} \mathrm{CR} 1^{\text {lo }} \mathrm{Ly} 6$ $\mathrm{C}^{-} \mathrm{Ly}_{6 \mathrm{G}}{ }^{-}$cells, resembling in vitro grown LTC-DC $(32,33)$. In defining L-DC, populations of monocytes and granulocytes were also closely considered. Another outcome has therefore been the definition of eosinophils in spleen as CD11b ${ }^{\text {hi }}$ CD $11 c^{-}$Ly6C ${ }^{+}$Ly $6 \mathrm{G}^{-}$Siglec- $\mathrm{F}^{+}$cells. Ly6C ${ }^{\mathrm{lo}}$-resident monocytes in spleen have now been identified more completely as $\mathrm{CD} 11 \mathrm{~b}^{\text {hi }} \mathrm{CD} 11 \mathrm{c}^{\mathrm{lo}} \mathrm{Ly} 6 \mathrm{C}^{+}$ Ly6 $6{ }^{-} \mathrm{CD}_{43}{ }^{+} \mathrm{CX}_{3} \mathrm{CR}{ }^{\text {hi }}{ }^{\mathrm{CD}} 115^{+}$Siglec-F ${ }^{-}$cells. A study of subset prevalence in knockout mouse models confirmed the definition of L-DC in terms of their distinct lineage origin, establishing that L-DC develop independently of Batf3 expression essential for cDC development, and also independent of the FLT3L/GM-CSF growth factors necessary for $\mathrm{CDC}$ and monocyte development in spleen.

\section{AUTHOR CONTRIBUTIONS}

YH: performance of experiments, analysis and assembly of data, manuscript writing. JT: analysis and interpretation of data, manuscript review. HO: project design and management, planning experiment, analysis and assembly of data, manuscript writing.

\section{FUNDING}

This work was supported by project grant \#585443 funding from the National Health and Medical Research Council of Australia to HO. YH was supported by an ANU Graduate School scholarship. JT was supported by a CJ Martin Fellowship from the National Health and Medical Research Council of Australia.

\section{SUPPLEMENTARY MATERIAL}

The Supplementary Material for this article can be found online at http://journal.frontiersin.org/article/10.3389/fimmu.2015.00652

3. Auffray C, Fogg D, Garfa M, Elain G, Join-Lambert O, Kayal S, et al. Monitoring of blood vessels and tissues by a population of monocytes with patrolling behavior. Science (2007) 317:666-70. doi:10.1126/science.1142883

4. Onai N, Obata-Onai A, Schmid MA, Ohteki T, Jarrossay D, Manz MG. Identification of clonogenic common Fllt3+M-CSFR+ plasmactyoid and conventional dendritic cell progneitors in mouse bone marrow. Nat Immunol (2007) 8:1207-16. doi:10.1038/ni1518 
5. Naik SH, Sathe P, Park HY, Metcalf D, Proietto AI, Daic A, et al. Development of plasmacytoid and conventional dendritic cell subtypes from single precursor cells derived in vitro and in vivo. Nat Immunol (2007) 8:1217-26. doi:10.1038/ni1522

6. Gordon S, Taylor PR. Monocyte and macrophage heterogeneity. Nat Rev Immunol (2005) 5:953-64. doi:10.1038/nri1733

7. Geissmann F, Jung S, Littman DR. Blood monocytes consist of two principal subsets with distinct migratory properties. Immunity (2003) 19:71-82. doi:10.1016/S1074-7613(03)00174-2

8. Carlin LM, Stamatiades EG, Auffray C, Hanna RN, Glover L, Vizcay-Barrena $G$, et al. Nr4a1-dependent Ly6C(low) monocytes monitor endothelial cells and orchestrate their disposal. Cell (2013) 153:362-75. doi:10.1016/j. cell.2013.03.010

9. Nahrendorf M, Swirski FK, Aikawa E, Stangenberg L, Wurdinger T, Figueiredo $\mathrm{JL}$, et al. The healing myocardium sequentially mobilizes two monocyte subsets with divergent and complementary functions. J Exp Med (2007) 204:3037-47. doi:10.1084/jem.20070885

10. Sunderkötter C, Nikolic T, Dillon MJ, Van Rooijen N, Stehling M, Drevets DA, et al. Subpopulations of mouse blood monocytes differ in maturation stage and inflammatory response. J Immunol (2004) 172:4410-7. doi:10.4049/ jimmunol.172.7.4410

11. Tacke F, Alvarez D, Kaplan TJ, Jakubzick C, Spanbroek R, Llodra J, et al. Monocyte subsets differentially employ CCR2, CCR5, and CX3CR1 to accumulate within atherosclerotic plaques. J Clin Invest (2007) 117:185-94. doi:10.1172/JCI28549

12. Ginhoux F, Greter M, Leboeuf M, Nandi S, See P, Gokhan S, et al. Fate mapping analysis reveals that adult microglia derive from primitive macrophages. Science (2010) 330:841-5. doi:10.1126/science.1194637

13. Guilliams M, De Kleer I, Henri S, Post S, Vanhoutte L, De Prijck S, et al. Alveolar macrophages develop from fetal monocytes that differentiate into long-lived cells in the first week of life via GM-CSF. J Exp Med (2013) 210:1977-92. doi:10.1084/jem.20131199

14. Hashimoto D, Chow A, Noizat C, Teo P, Beasley MB, Leboeuf M, et al. Tissueresident macrophages self-maintain locally throughout adult life with minimal contribution from circulating monocytes. Immunity (2013) 38:792-804. doi:10.1016/j.immuni.2013.04.004

15. Schulz C, Gomez Perdiguero E, Chorro L, Szabo-Rogers H, Cagnard N, Kierdorf K, et al. A lineage of myeloid cells independent of Myb and hematopoietic stem cells. Science (2012) 336:86-90. doi:10.1126/science.1219179

16. Swirski FK, Nahrendorf M, Etzrodt M, Wildgruber M, Cortez-Retamozo $\mathrm{V}$, Panizzi P, et al. Identification of splenic reservoir monocytes and their deployment to inflammatory sites. Science (2009) 325:612-6. doi:10.1126/ science. 1175202

17. Rose S, Misharin A, Perlman H. A novel Ly6C/Ly6G-based strategy to analyze the mouse splenic myeloid compartment. Cytometry A (2012) 81 A:343-50. doi:10.1002/cyto.a.22012

18. Galli SJ, Borregaard N, Wynn TA. Phenotypic and functional plasticity of cells of innate immunity: macrophages, mast cells and neutrophils. Nat Immunol (2011) 12:1035-44. doi:10.1038/ni.2109

19. Voehringer D, Van Rooijen N, Locksley RM. Eosinophils develop in distinct stages and are recruited to peripheral sites by alternatively activated macrophages. J Leukoc Biol (2007) 81:1434-44. doi:10.1189/jlb.1106686

20. Heath WR, Belz GT, Behrens GMN, Smith CM, Forehan SP, Parish IA, et al. Cross-presentation, dendritic cell subsets, and the generation of immunity to cellular antigens. Immunol Rev (2004) 199:9-26. doi:10.1111/j.0105-2896.2004.00142.x

21. Naik SH. Demystifying the development of dendritic cell subtypes, a little. Immunol Cell Biol (2008) 86:439-52. doi:10.1038/icb.2008.28

22. Vremec D, Pooley J, Hochrein H, Wu L, Shortman K. CD4 and CD8 expression by dendritic cell subtypes in mouse thymus and spleen. JImmunol (2000) 164:2978-86. doi:10.4049/jimmunol.164.6.2978

23. Hochrein H, Shortman K, Vremec D, Scott B, Hertzog P, O’Keeffe M. Differential production of IL-12, IFN- $\alpha$, and IFN- $\beta$ by mouse dendritic cell subsets. J Immunol (2001) 166:5448-55. doi:10.4049/jimmunol.166.9.5448

24. Pelayo R, Hirose J, Huang J, Garrett KP, Delogu A, Busslinger M, et al. Derivation of 2 categories of plasmacytoid dendritic cells in murine bone marrow. Blood (2005) 105:4407-15. doi:10.1182/blood-2004-07-2529

25. Geissmann F, Auffray C, Palframan R, Wirrig C, Ciocca A, Campisi L, et al. Blood monocytes: distinct subsets, how they relate to dendritic cells, and their possible roles in the regulation of T-cell responses. Immunol Cell Biol (2008) 86:398-408. doi:10.1038/icb.2008.19

26. León B, López-Bravo M, Ardavín C. Monocyte-derived dendritic cells. Semin Immunol (2005) 17:313-8. doi:10.1016/j.smim.2005.05.013

27. León B, López-Bravo M, Ardavín C. Monocyte-derived dendritic cells formed at the infection site control the induction of protective T helper 1 responses against Leishmania. Immunity (2007) 26:519-31. doi:10.1016/j. immuni.2007.01.017

28. Quah B, Ni K, O’Neill HC. In vitro hematopoiesis produces a distinct class of immature dendritic cells from spleen progenitors with limited $\mathrm{T}$ cell stimulation capacity. Int Immunol (2004) 16:567-77. doi:10.1093/intimm/ dxh060

29. Wilson HL, Ni K, O’Neill HC. Identification of progenitor cells in long-term spleen stromal cultures that produce immature dendritic cells. Proc Natl Acad Sci U S A (2000) 97:4784-9. doi:10.1073/pnas.080278897

30. Wilson NS, El-Sukkari D, Villadangos JA. Dendritic cells constitutively present self antigens in their immature state in vivo and regulate antigen presentation by controlling the rates of MHC class II synthesis and endocytosis. Blood (2004) 103:2187-95. doi:10.1182/blood-2003-08-2729

31. Periasamy P, Tan JKH, Griffiths KL, O’Neill HC. Splenic stromal niches support hematopoiesis of dendritic-like cells from precursors in bone marrow and spleen. Exp Hematol (2009) 37:1060-71. doi:10.1016/j.exphem.2009.06.001

32. Petvises S, O'Neill HC. Characterisation of dendritic cells arising from progenitors endogenous to murine spleen. PLoS One (2014) 9(2):e88311. doi:10.1371/journal.pone.0088311

33. Periasamy P, O’Neill HC. Stroma-dependent development of two dendritic-like cell types with distinct antigen presenting capability. Exp Hematol (2013) 41:281-92. doi:10.1016/j.exphem.2012.11.003

34. Xu Y, Zhan Y, Lew AM, Naik SH, Kershaw MH. Differential development of murine dendritic cells by GM-CSF versus Flt3 ligand has implications for inflammation and trafficking. JImmunol (2007) 179:7577-84. doi:10.4049/ jimmunol.179.11.7577

35. Petvises S, Talaulikar D, O'Neill HC. Delineation of a novel dendritic-like subset in human spleen. Cell Mol Immunol (2015). doi:10.1038/cmi.2015.16

36. Tan JKH, Quah BJC, Griffiths KL, Periasamy P, Hey YY, O’Neill HC. Identification of a novel antigen cross-presenting cell type in spleen. $J$ Cell Mol Med (2011) 15:1189-99. doi:10.1111/j.1582-4934.2010.01089.x

37. Asselin-Paturel C, Boonstra A, Dalod M, Durand I, Yessaad N, DezutterDambuyant C, et al. Mouse type I IFN-producing cells are immature APCs with plasmacytoid morphology. Nat Immunol (2001) 2:1144-50. doi:10.1038/ ni736

38. Björck P. Isolation and characterization of plasmacytoid dendritic cells from Flt3 ligand and granulocyte-macrophage colony-stimulating factor-treated mice. Blood (2001) 98:3520-6. doi:10.1182/blood.V98.13.3520

39. Nakano H, Yanagita M, Gunn MD. CD11c+B220+Gr-1+ cells in mouse lymph nodes and spleen display characteristics of plasmacytoid dendritic cells. J Exp Med (2001) 194:1171-8. doi:10.1084/jem.194.8.1171

40. Jaiswal H, Kaushik M, Sougrat R, Gupta M, Dey A, Verma R, et al. Batf3 and Id2 have a synergistic effect on Irf8-directed classical CD8 $\alpha+$ dendritic cell development. J Immunol (2013) 191:5993-6001. doi:10.4049/ jimmunol.1203541

41. Tussiwand R, Lee WL, Murphy TL, Mashayekhi M, Kc W, Albring JC, et al. Compensatory dendritic cell development mediated by BATF-IRF interactions. Nature (2012) 490:502-7. doi:10.1038/nature11531

42. Auffray C, Sieweke MH, Geissmann F. Blood monocytes: development, heterogeneity, and relationship with dendritic cells. Annu Rev Immunol (2009) 27:669-92. doi:10.1146/annurev.immunol.021908.132557

43. Dai XM, Ryan GR, Hapel AJ, Dominguez MG, Russell RG, Kapp S, et al. Targeted disruption of the mouse colony-stimulating factor 1 receptor gene results in osteopetrosis, mononuclear phagocyte deficiency, increased primitive progenitor cell frequencies, and reproductive defects. Blood (2002) 99:111-20. doi:10.1182/blood.V99.1.111

44. Sasmono RT, Oceandy D, Pollard JW, Tong W, Pavli P, Wainwright BJ, et al. A macrophage colony-stimulating factor receptor-green fluorescent protein transgene is expressed throughout the mononuclear phagocyte system of the mouse. Blood (2003) 101:1155-63. doi:10.1182/blood-2002-02-0569

45. Dunay IR, Fuchs A, David Sibley L. Inflammatory monocytes but not neutrophils are necessary to control infection with Toxoplasma gondii in mice. Infect Immun (2010) 78:1564-70. doi:10.1128/IAI.00472-09 
46. Fogg DK, Sibon C, Miled C, Jung S, Aucouturier P, Littman DR, et al. A clonogenic bone harrow progenitor specific for macrophages and dendritic cells. Science (2006) 311:83-7. doi:10.1126/science.1117729

47. Jung S, Aliberti J, Graemmel P, Sunshine MJ, Kreutzberg GW, Sher A, et al. Analysis of fractalkine receptor CX3CR1 function by targeted deletion and green fluorescent protein reporter gene insertion. Mol Cell Biol (2000) 20:4106-14. doi:10.1128/MCB.20.11.4106-4114.2000

48. Palframan RT, Jung S, Cheng G, Weninger W, Luo Y, Dorf M, et al. Inflammatory chemokine transport and presentation in HEV: a remote control mechanism for monocyte recruitment to lymph nodes in inflamed tissues. J Exp Med (2001) 194:1361-73. doi:10.1084/jem.194.9.1361

49. Auffray C, Fogg DK, Narni-Mancinelli E, Senechal B, Trouillet C, Saederup N, et al. CX 3CR1 + CD115 + CD135 + common macrophage/DC precursors and the role of CX 3CR1 in their response to inflammation. J Exp Med (2009) 206:595-606. doi:10.1084/jem.20081385

50. Bar-On L, Birnberg T, Lewis KL, Edelson BT, Bruder D, Hildner K, et al. $\mathrm{CX} 3 \mathrm{CR} 1+\mathrm{CD} 8 \alpha+$ dendritic cells are a steady-state population related to plasmacytoid dendritic cells. Proc Natl Acad Sci U S A (2010) 107:14745-50. doi:10.1073/pnas.1001562107

51. Hildner K, Edelson BT, Purtha WE, Diamond M, Matsushita H, Kohyama $\mathrm{M}$, et al. Batf3 deficiency reveals a critical role for $\mathrm{CD} 8 \alpha+$ dendritic cells in cytotoxic T cell immunity. Science (2008) 322:1097-100. doi:10.1126/ science. 1164206

52. Murphy TL, Tussiwand R, Murphy KM. Specificity through cooperation: BATF-IRF interactions control immune-regulatory networks. Nat Rev Immunol (2013) 13:499-509. doi:10.1038/nri3470

53. Satpathy AT, Wu X, Albring JC, Murphy KM. Re(de)fining the dendritic cell lineage. Nat Immunol (2012) 13:1145-54. doi:10.1038/ni.2467

54. McKenna HJ, Stocking KL, Miller RE, Brasel K, De Smedt T, Maraskovsky E, et al. Mice lacking flt3 ligand have deficient hematopoiesis affecting hematopoietic progenitor cells, dendritic cells, and natural killer cells. Blood (2000) 95:3489-97.

55. Maraskovsky E, Brasel K, Teepe M, Roux ER, Lyman SD, Shortman K, et al. Dramatic increase in the number of functionally mature dendritic cells in Flt3 ligand-treated mice: multiple dendritic cell subpopulations identified. J Exp Med (1996) 184:1953-62. doi:10.1084/jem.184.5.1953

56. Pulendran B, Lingappa J, Kennedy MK, Smith J, Teepe M, Rudensky A, et al. Developmental pathways of dendritic cells in vivo: distinct function, phenotype, and localization of dendritic cell subsets in FLT3 ligand-treated mice. J Immunol (1997) 159:2222-31.

57. Shurin MR, Pandharipande PP, Zorina TD, Haluszczak C, Subbotin VM, Hunter $\mathrm{O}$, et al. FLT3 ligand induces the generation of functionally active dendritic cells in mice. Cell Immunol (1997) 179:174-84. doi:10.1006/ cimm.1997.1152

58. Beaudin AE, Boyer SW, Forsberg EC. Flk2/Flt3 promotes both myeloid and lymphoid development by expanding non-self-renewing multipotent hematopoietic progenitor cells. Exp Hematol (2014) 42:218-29. doi:10.1016/j. exphem.2013.11.013

59. Karsunky H, Merad M, Cozzio A, Weissman IL, Manz MG. Flt3 ligand regulates dendritic cell development from Flt3+ lymphoid and myeloid-committed progenitors to Flt3+ dendritic cells in vivo. J Exp Med (2003) 198:305-13. doi: $10.1084 /$ jem. 20030323

60. Serbina NV, Jia T, Hohl TM, Pamer EG. Monocyte-mediated defense against microbial pathogens. Annu Rev Immunol (2008) 26:421-52. doi:10.1146/ annurev.immunol.26.021607.090326

61. Berthier R, Martinon-Ego C, Laharie AM, Marche PN. A two-step culture method starting with early growth factors permits enhanced production of functional dendritic cells from murine splenocytes. J Immunol Methods (2000) 239:95-107. doi:10.1016/S0022-1759(00)00186-1

62. Inaba $\mathrm{K}$, Inaba $\mathrm{M}$, Deguchi $\mathrm{M}$, Hagi $\mathrm{K}$, Yasumizu R, Ikehara $\mathrm{S}$, et al. Granulocytes, macrophages, and dendritic cells arise from a common major histocompatibility complex class II-negative progenitor in mouse bone marrow. Proc Natl Acad Sci U S A (1993) 90:3038-42. doi:10.1073/pnas.90.7.3038

63. Kingston D, Schmid MA, Onai N, Obata-Onai A, Baumjohann D, Manz MG. The concerted action of GM-CSF and Flt3-ligand on in vivo dendritic cell homeostasis. Blood (2009) 114:835-43. doi:10.1182/blood-2009-02-206318
64. Vremec D, Lieschke GJ, Dunn AR, Robb L, Metcalf D, Shortman K. The influence of granulocyte/macrophage colony-stimulating factor on dendritic cell levels in mouse lymphoid organs. Eur J Immunol (1997) 27:40-4. doi:10.1002/ eji. 1830270107

65. Guilliams M, Ginhoux F, Jakubzick C, Naik SH, Onai N, Schraml BU, et al. Dendritic cells, monocytes and macrophages: a unified nomenclature based on ontogeny. Nat Rev Immunol (2014) 14:571-8. doi:10.1038/nri3712

66. Bochner BS. Siglec- 8 on human eosinophils and mast cells, and Siglec-F on murine eosinophils, are functionally related inhibitory receptors. Clin Exp Allergy (2009) 39:317-24. doi:10.1111/j.1365-2222.2008.03173.x

67. Guo JP, Nutku E, Yokoi H, Schnaar RL, Zimmermann N, Bochner BS. Siglec-8 and siglec-F: inhibitory receptors on eosinophils, basophils, and mast cells. Allergy Clin Immunol Int (2007) 19:54-9. doi:10.1027/0838-1925.19.2.54

68. Domínguez PM, Ardavín C. Differentiation and function of mouse monocyte-derived dendritic cells in steady state and inflammation. Immunol Rev (2010) 234:90-104. doi:10.1111/j.0105-2896.2009.00876.x

69. Mori Y, Iwasaki H, Kohno K, Yoshimoto G, Kikushige Y, Okeda A, et al. Identification of the human eosinophil lineage-committed progenitor: revision of phenotypic definition of the human common myeloid progenitor. $J$ Exp Med (2009) 206:183-93. doi:10.1084/jem.20081756

70. Langerhans P. Uber die nerven der menschlichen haut. Arch Pathol Anat (1868) 44:325-37. doi:10.1007/BF01959006

71. Silberberg I. Apposition of mononuclear cells to langerhans cells in contact allergic reactions. An ultrastructural study. Acta Derm Venereol (1973) 53:1-12.

72. Hinton R, O'Neill H. Extramedullary hematopoiesis leading to the production of a novel antigen presenting cell type in murine spleen. Int J Med Biol Front (2012) 18:569-81.

73. Petvises S, O’Neill HC. Distinct progenitor origin distinguishes a lineage of dendritic-like cells in spleen. Front Immunol (2014) 4:501. doi:10.3389/ fimmu.2013.00501

74. Liu K, Victora GD, Schwickert TA, Guermonprez P, Meredith MM, Yao K, et al. In vivo analysis of dendritic cell development and homeostasis. Science (2009) 324:392-7. doi:10.1126/science.1170540

75. Kurachi M, Barnitz RA, Yosef N, Odorizzi PM, DiIorio MA, Lemieux ME, et al. The transcription factor BATF operates as an essential differentiation checkpoint in early effector CD8+ T cells. Nat Immunol (2014) 15(4):373-83. doi:10.1038/ni.2834

76. Schraml BU, Hildner K, Ise W, Lee WL, Smith WAE, Solomon B, et al. The AP-1 transcription factor Batf controls T H 17 differentiation. Nature (2009) 460:405-9. doi:10.1038/nature08114

77. Bettelli E, Carrier Y, Gao W, Korn T, Strom TB, Oukka M, et al. Reciprocal developmental pathways for the generation of pathogenic effector TH17 and regulatory T cells. Nature (2006) 441:235-8. doi:10.1038/nature04753

78. Brüstle A, Heink S, Huber M, Rosenplänter C, Stadelmann C, Yu P, et al. The development of inflammatory TH-17 cells requires interferon-regulatory factor 4. Nat Immunol (2007) 8:958-66. doi:10.1038/ni1500

79. Waskow C, Liu K, Darrasse-Jèze G, Guermonprez P, Ginhoux F, Merad M, et al. The receptor tyrosine kinase Flt3 is required for dendritic cell development in peripheral lymphoid tissues. Nat Immunol (2008) 9:676-83. doi:10.1038/ ni. 1615

80. Stanley E, Lieschke GJ, Grail D, Metcalf D, Hodgson G, Gall JAM, et al. Granulocyte/macrophage colony-stimulating factor-deficient mice show no major perturbation of hematopoiesis but develop a characteristic pulmonary pathology. Proc Natl Acad Sci U S A (1994) 91:5592-6. doi:10.1073/ pnas.91.12.5592

Conflict of Interest Statement: The authors declare that the research was conducted in the absence of any commercial or financial relationships that could be construed as a potential conflict of interest.

Copyright $\odot 2016$ Hey, Tan and O'Neill. This is an open-access article distributed under the terms of the Creative Commons Attribution License (CC BY). The use, distribution or reproduction in other forums is permitted, provided the original author(s) or licensor are credited and that the original publication in this journal is cited, in accordance with accepted academic practice. No use, distribution or reproduction is permitted which does not comply with these terms. 